\title{
NLR and PLR as potential markers of disease activity in patients with ankylosing spondylitis?
}

\author{
Tolga Düzenli ${ }^{*}$ (D) and Emre Ata $^{2}$ (D)
}

\section{Dear Editor,}

We read the recently published article entitled 'Neutrophil/lymphocyte and platelet/ lymphocyte ratios as potential markers of disease activity in patients with Ankylosing spondylitis: a case-control study' by Al-Osami $\mathrm{MH}$ et al. [1] with interest. In the article authors aimed to evaluate the NLR and PLR as potential markers of disease activity in patients with ankylosing spondylitis. At the end of the article, the authors have pointed out that there was a statistically significant difference in the NLR and PLR between the active and inactive ankylosing spondylitis patients. And they concluded that PLR may be used as a useful marker in the assessment and monitoring of disease activity in AS together with acute phase reactants such as the ESR. The availability of this parameters at no additional cost may encourage its utilization in clinical practice. We would like to thank to the authors for their comprehensive contribution.

NLR is a globally available and inexpensive laboratory parameter, which is used to test systemic inflammation. In previous papers, it was shown that chronic hepatitis $B$ and/or $\mathrm{C}$ infection, renal failure, diabetes mellitus, valvular heart diseases, acute coronary syndromes, thyroid functional abnormalities, metabolic syndrome, essential hypertension, and many inflammatory diseases may potentially affect the NLR $[2,3]$. And also the main limitations of PLR studies are preanalytical faults, inadequate standardization of laboratory measurements, and inappropriate subject selection [4]. Thus, it would be more relevant if $\mathrm{Al}$-Osami $\mathrm{MH}$ et al. had mentioned these NLR and PLR-affecting factors while evaluating the relationship between NLR and PLR in patients with

\footnotetext{
* Correspondence: tolgaduzenli@yahoo.com

${ }^{1}$ Department of Gastroenterology, Hitit University Erol Olcok Training and

Research Hospital, Çepni, İnönü Cd. No:176, 19040 Çorum, Turkey

Full list of author information is available at the end of the article
}

ankylosing spondylitis. And also, as an important limitation of study, it would be more objective if a larger number of patients were included in this current research. Moreover, medication may easily alter NLR and PLR, so it would have been useful if the patients were described in greater detail in terms of, anti-inflammatory drugs, antiviral agents, immunosuppressive drugs, and/or other medications. In addition, it would also have been better if the authors indicated the elapsed time between taking the blood samples and measuring NLR and PLR, since waiting period prior to analysis may affect this laboratory parameters $[2,3]$.

We believe that the findings of Al-Osami $\mathrm{MH}$ et al. [1] will lead to further research concerning the relationship between NLR, PLR and ankylosing spondylitis. In addition to that, it should be kept in mind that NLR and PLR may not secure true information about disease activity in patients with ankylosing spondylitis.

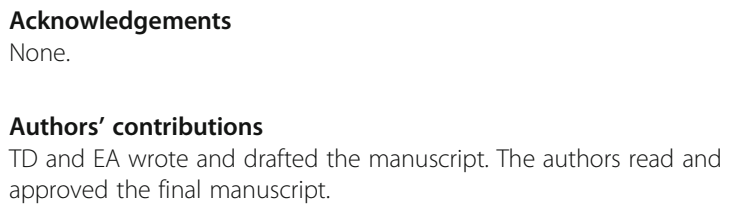

Authors' contributions

TD and EA wrote and drafted the manuscript. The authors read and approved the final manuscript.

\section{Funding}

There has been no financial support for this work.

Availability of data and materials

Not applicable.

Ethics approval and consent to participate Not applicable.

Consent for publication

Not applicable.

Competing interests

The authors declare that they have no competing interests. 


\section{Author details}

'Department of Gastroenterology, Hitit University Erol Olcok Training and Research Hospital, Çepni, Inönü Cd. No:176, 19040 Çorum, Turkey.

${ }^{2}$ Department of Physical Medicine and Rehabilitation, Sultan Abdulhamid

Han Training and Research Hospital, Istanbul, Turkey.

Received: 9 February 2020 Accepted: 16 April 2020

Published online: 01 May 2020

\section{References}

1. Al-Osami MH, Awadh NI, Khalid KB, Awadh Al. Neutrophil/lymphocyte and platelet/lymphocyte ratios as potential markers of disease activity in patients with ankylosing spondylitis: a case-control study. Adv Rheumatol. 2020;60(1):13.

2. Düzenli T, Çakır Güney B, Tanoğlu A, Kaplan M, Akyol T. Does Gilbert syndrome have an effect on the hematologic parameters? GMJ. 2020;31(1): 15-8. https://doi.org/10.12996/gmj.2020.04.

3. Karakonstantis S, Kalemaki D, Tzagkarakis E, Lydakis C. Pitfalls in studies of eosinopenia and neutrophil-to-lymphocyte count ratio. Infect Dis (Lond). 2018;50(3):163-74.

4. Gasparyan AY, Ayvazyan L, Mukanova U, Yessirkepov M, Kitas GD. The platelet-to-lymphocyte ratio as an inflammatory marker in rheumatic diseases. Ann Lab Med. 2019;39(4):345-57.

\section{Publisher's Note}

Springer Nature remains neutral with regard to jurisdictional claims in published maps and institutional affiliations.

- fast, convenient online submission

- thorough peer review by experienced researchers in your field

- rapid publication on acceptance

- support for research data, including large and complex data types

- gold Open Access which fosters wider collaboration and increased citations

- maximum visibility for your research: over $100 \mathrm{M}$ website views per year

At BMC, research is always in progress. 